TEXT Vol 21 No 2 (October 2017)

\title{
Poetry and prose contents
}

- Megan Anning, Erato page 2

- Yuan Changming, 5 Poems page 12

- $\quad$ Amy T Matthews, Thinking About Camels page 16

- Peter Nash, Murder in the Office of Final Editing page 22

- Chelsea Avard, Blue Eyes page 25 


\section{TEXT prose}

\section{Megan Anning}

\section{Erato}

Clio met Tomas one night at a gathering at Max's place. [1] She had recently returned to Brisbane when she ran into Max, an old acquaintance. Clio told him she was looking for a place to stay. He offered her the tiny flat above his in West End, a bohemian part of town where artists and other outsiders hung outside cafes and smoked cigarettes. She moved in immediately, lined up a job at a small college in the city, and lived each day without much thought for the future.

Clio was ensconced in the kitchen talking to a woman who was older, and sharp witted with long, black hair pulled tight into a bun on top of her head. She told Clio that while she was in administration, her passion was for the arts; she had a show coming up at Soapbox, a gallery in the centre of town.

'Oh,' said Clio with raised eyebrows.

The woman's eyes shone. Her glasses were enormous and had thick black rims. Her dangling earrings swung violently. She was becoming more excited as she explained her concept. It involved knitted animals. Clio imagined woolen bunnies or lambs with sagging ears, spread across a white gallery floor.

The woman said: 'What do you do?'

Clio paused. 'I'm a teacher.'

'Oh - what do you teach?'

'English. As a second language.'

'Do you enjoy it?'

'It has its moments.'

The woman smiled. They both sipped their wine. Clio added that she liked to play the piano and write poetry in her spare time before the conversation steered back to the woman's show. The words washed over Clio like waves. She was being eroded, whittled down, nullified. She didn't know much at all about art when it came down to it, and this fact bothered her for reasons she didn't yet fully understand.

Max, who was busy being the host, was the only person Clio knew. She tapped a fingernail on her glass.

'It's undervalued,'said the woman, whose eyes glowed brighter, in a half-crazed sort of way. Clio laughed along. She thought she detected sarcasm, but couldn't be sure.

'Knitting is a forsaken art! A part of the fabric of womankind!' In the stark kitchen light, Clio saw a face reflected in the woman's glasses. The same face peered out of each lens. For a moment, she didn't know who it was. Then she recognized herself - her dyed blonde hair, her eager eyes. [2]

Tomas waltzed past the doorway behind them. Clio saw him. He was gorgeous: frothy black hair, a rash of stubble, a dangling cigarette. He swaggered rather than walked. 
Later, his dark shape hung in her peripheral vision. He was leaning against a pole outside, poised like a Grecian statue. Clio listened for his voice; she sucked smoke from her cigarette. People stood around him in reverence. Tomas wasn't overly talkative, but Clio was mesmerized: his eyes were dark, yet lit up from within, as though a fire burned and crackled inside; and when he smiled, there was an indefinable radiance about him, despite the creeping brown stains on his teeth. Clio pretended to be interested in a conversation which was taking place around her. She smiled. She sipped her wine. She laughed at appropriate times. But before long, her gaze flitted to Tomas. They exchanged glances. The noise of the party melted into a distant rumble, and soon, they fell into a sudden, passionate love, the kind found in movies.

It wasn't long before she was packing up her possessions to go to live with Tomas in his small studio flat nearby. The morning of the move was glorious with birds chirping outside and early spring sun lighting up the rooms. All of it heralded their new life together.

She had few things other than a huge number of books. Clio started at the bookshelf. Tomas was in the other room swishing a broom across the floor. She piled the books into boxes, as she had done many times before, for Clio was acutely aware of their preciousness, and of how she longed to learn their secrets, their lessons. She had lugged them around since university, rarely letting one go as she moved from place to place. Many of their covers were softened and torn from wear; pages were folded down at the tops or had come dangerously loose from the spine. She frowned with each book that she picked up, for Clio had read very few of them all the way to the end.

But this was not for want of trying. In fact, Clio began reading her books most days. The trouble was that she scarcely got a quarter of the way through before a sickening sense of grief wound its way into her stomach, causing her to double over and retch in pain.

Although sometimes, when she least expected it, she could read a book from start to finish. Poetry was safe too. Apart from epics or narratives, Clio could read poems without any ill effects. The Wasteland never caused any trouble: it was immune to Clio's sickness, and she could read it all the way through with ease. [3] The same went for David Gascoyne's poems. When she first read 'And the Seventh Dream is the Dream of Isis', she imagined herself singing while her hair stood on end, illuminated like a million little glowworms. [4]

Even so, whenever the grief overtook her, especially when she was partway through a book, she couldn't help but feel resentful. The idea that she might never travel beyond the exposition stage, or see past the climactic moment to the ending, was mortifying for Clio. She would often toss an unfinished book aside and lie listlessly on her bed, looking up at the ceiling, or at the bookshelves. Sometimes the books seemed to stare at her, and whisper among themselves.

She had sought help from counsellors, doctors, and psychologists. But nothing and no one had been able to cure her strange and curious malady. She picked up Down Among the Women. She caressed its front. On the pink cover was a picture of a smiling woman holding a tray of food. Her blouse was collared and buttoned all the way up to the neck. A cupcake decorated with a plume of cream and raspberries was in the corner, just above a martini glass that was tilted on its side. Liquid spilled out of it. Clio felt a sudden sense of urgency. She wanted to read it. She turned it over and read the words on the back:

An articulate and blistering howl of rage at the female condition.

Down among the women. What a place to be!

Clio held the book against her chest. She felt her heart beating underneath. Then she put it into a box.

Tomas came to the doorway. Without a word she went to him. They kissed. The kiss went on for a long time. Clio didn't want to remember who she was. [5]

But at night, beneath closed eyelids, there was no escape: shards, snippets of memory came rushing back. In her dreams, they formed into a strange patchwork. She had a recurring 
dream. She was in a tunnel. She walked towards a prick of light far off in the distance. The light came closer - it became bigger till it revealed a beautiful, laughing woman whose wild, black hair writhed like snakes. Clio didn't know if the woman was laughing with her or if she was being mocked. [6]

The dream first appeared years earlier, when Clio was studying law at university. She was a good, dutiful daughter. It had begun well enough. Clio attended classes and submitted assignments. Though it wasn't long before she started to feel hollow, as if air filtered right through a hole in her middle. She tried to tell people. But the right words were never there when she needed them. The fat law books became heavier, more difficult to carry, until they remained on her desk like dusty monoliths, left open and untouched for months at a time. She began to drink. Empty bottles stacked up. She hid them under the bed.

One day, her parents were called to the college. Clio hadn't been seen around the halls for days. Sister Theresa had gone to investigate.

'Holy Mary, Mother of God!'

Sister's voice could be heard trailing out of Clio's room and down the hall. Girls came out of their rooms, eager to see what the commotion was about. Clio was found splayed on her back on the bed, naked, clutching The Penguin Book of Romantic Poetry to her chest. The room was in disarray, strewn with books: AS Byatt, Virginia Woolf, Sylvia Plath. The list went on. Some were left open, face down on the floor, their spines buckling from pressure; others teetered in piles on the armchair, and on the bedside table. Dead Poets' Society was playing on the television. Clio was motionless, in a catatonic state, like she had been turned to stone. She stared up at the ceiling, not once blinking, not even when Sister Theresa leant in close and patted her cheek. She spoke into her ear.

'Clio, can you hear me?'

But she didn't answer. Sister stood up and looked around. A thick book lay open on the desk. On top of it was a smaller book. Sister switched on the lamp. She leant in close to read, before recoiling with a gasp. She flipped the cover over to inspect the title.

'Tender buttons?' Sister said the words aloud, perplexed.

She picked up the book; adjusted her glasses. Her eyes grew wider as they scanned the first page; her mouth was agape. She couldn't believe what she was reading. Sentences jumped out at her. She read them to herself, punctuating each with a question mark: There is no gratitude in mercy and in medicine? Sugar is not a vegetable? A single image is not splendour? Sister shut the book. She had read enough. Clio remained unblinking on the bed. Tacked on the wall above her was a large Dali print with blue and brown hues. Melted clocks peered out from within. [7]

Eventually, Clio was able to put the incident behind her thanks to a short stay in hospital. A clean-shaven doctor told her, over the top of his clipboard, the good news: exhaustion - a diagnosis which wasn't too serious.

'Nothing that rest and relaxation can't cure,' said the man cheerily.

Some pills to buoy her spirits would be needed in the short term, but things would get back to normal in no time. Clio stared at the clean white of the doctor's coat as he filled out her prescription.

Her parents spoke in hushed tones when they picked her up from the hospital. Silence filled the car during the drive home. Her mother looked out of the window in dismay and shock. Clio's memory was fuzzy. She couldn't be sure of what, exactly, had happened. She stared out the window at the world which whipped past.

After some time, she managed to finish a degree in semantics before heading overseas to teach English. But Clio felt, keenly, the sense of having been thwarted, of having lost something precious, and she carried with her, at all times, the grief for that lost thing. But 
never was it more intensely felt than when she tried to read books. Non-fiction was not a problem. But for some unknown reason, Clio found fiction books incredibly painful, because she had lost the ability to read them. It was easy for her not to want to read books when Tomas was around.

At first he was an exceptional lover. They spent hours in bed together, only getting up for food and other necessities. His body glowed with a warm caramel light. After they made love, Clio sometimes took a moment to bask in his aura, which seemed to her to be otherworldly and ethereal.

She was shown his art works, his videos of various performances from years past. Clio was stunned. In one performance, he lay in the street with his head in a cage. The cage was filled with breadcrumbs. A congregation of pigeons surrounded him; they pecked and cooed at his head. His body lay motionless on the pavement, dressed in a suit. [8] He had a trove of artworks which cemented, for Clio, his genius. She felt he could just about walk on water.

He would present Clio with quirky, unexpected gifts - a necklace with a pendant of a cherub he had found in an op shop around the corner; a sudden feast of exotic fruit, caviar and champagne; a book of photos he had taken of her while she slept - close up shots of her eyelids. He would go to great lengths to explain how each photo captured her eyeballs in different positions, moving in the throes of deep sleep, in dreams.

Books were not nearly as scintillating, as enrapturing as Tomas. Clio was happy to have somebody to wrap herself around. One day, when she had her arms clasped around his neck, with their faces close, Tomas told her that Clio was the name of one of the nine muses in Greek mythology, the deity of history who carries an open book. A fierce look came over his face.

'But I think you should have been named Erato.'

'Why?'

'Because I'm forever falling in love with you. You're my yin.'

She answered. 'You're my yang.'

'Like the sun and the moon.'

'And our children are all the shining stars.'

They were happy for a time. Clio went to work in the city during the day. Tomas, having lost his job washing dishes early on in the piece, was content to work on his art at home. At night, they attended parties and art exhibitions, smoked cigarettes and recited poetry to each other.

But sometimes, Clio would look at the people around her and wonder whether anyone would notice if she stayed amidst the noise or quietly left. Everybody was busy discussing important, significant things, about art, about their projects, their friends, their aspirations. Everybody had their place and purpose.

At home, Tomas was often moody. Clio would return from work to find the place a mess and Tomas pacing, smoking furiously, garbling about a failed art project, or an unpaid debt, or some other problem. Her efforts to placate him failed. They began to argue. Afterwards, they would make up, and the cycle began afresh. Clio felt their life begin to sway like a boat on a choppy sea. In the throes of an argument she heard herself cry out.

'Why do I feel like I'm on a leaking boat with you?'

Tomas didn't reply. 
Their fights became more intense. She urged him to get a job, to get out of the house and into the world. But it was impossible. He seemed frightened of the life outside their kingdom.

Clio resolved to leave. But each time, she fell back into his arms. She was Erato, and they were forever falling in love.

Things began to look up when Tomas got a job at the Art Gallery. He would arrive home in the afternoons carrying food for dinner. Clio saw light shining from his face again. They talked about the future, about being together.

But again, they argued, and it seemed as though flames leapt between them. Tomas slept in the spare room.

The next day, on his way to work, Tomas was hit by a bus and died.

She stayed in the house for a month. His things surrounded her. Shoelaces hung down from empty shoes. Clothes were limp and lifeless on their hangers. She listened to classical music. She let it drift through the rooms. She lay in their bed and reached an arm across to his side. She cried in the shower. She cried in the kitchen. She wandered about the house and the streets in a somnambulist daze. In the stillness, in the living room, Clio sat motionless for hours at a time. Books on the shelves stared at her. She stared back.

One day, she went and stood by the bookshelf. She ran her fingers over the spines, slowly, in time with the arpeggios of Beethoven's 'Moonlight Sonata'. She picked up a book - Down Among the Women. She didn't give any thought to the past or future. Clio turned to page one. She began to read. The story started with Wanda, Scarlet's mother, talking about how the moon was a woman's timekeeper and nothing could change that fact of nature. But Clio didn't make it past the first page. She returned the book to its place on the shelf, resigned to the idea that she might never learn what happens in the end. [9]

\section{Notes}

[1] The opening line of my story is intended as a palimpsest of Guy de Maupassant's short story 'The Jewelry' (1884) which begins with the line: 'Having met the girl one evening, at the house of the office-superintendent, M. Lantin became enveloped in love as in a net' (Maupassant 1987). This allusion, although obscure, is the first of many intertextual references throughout 'Erato', which is a short story I wrote to experiment with Helene Cixous' notion of Écriture féminine (1976). In line with Cixous' claim that a woman writer is 'the erogeneity of the heterogeneous: airborne swimmer, in flight' (Cixous 1976: 889), I approached the writing of 'Erato' as a reader first, as though I was swimming in a language sea, reading, collecting and incorporating allusions to a myriad of different texts I found at hand. The exposure to these other voices not only enabled me to 'celebrate and play with the dissolution of the single subject', what Cixous terms the 'parental-conjugal phallocentrism' (1976: 876), but also to bring about Elaine Showalter's notion of a 'gynocritical' approach to literature which calls for 'an image of a female literary tradition which depends upon ... an implicit notion of intertextual relations between women writers' (Showalter 1979). I appropriated Maupassant's 'The Jewelry', a text written by a man about a male protagonist's search for happiness with deceitful and cruel women, and transformed it into a story about a female protagonist's search for personal and artistic fulfilment beyond her familial-conjugal relationships. return to text

[2] The older woman Clio encounters in the kitchen is intended to be representative of 'the electrifying Medusa archetype, with her staring eyes and snakes for hair...' (Alban 2013: 163), an archetype which has been embraced by Cixous in her essay 'The Laugh of the Medusa' (1976) as well as a plethora of women writers such as AS Byatt in her short story 'Body Art', Margaret Attwood in Cat's Eye, Sylvia Plath in her poem 'Medusa', and Angela Carter in 'The Bloody Chamber' (Alban 2013). Gillian ME Alban observes that the Medusa's gaze is often portrayed in these works as having both 'goddess and monster' qualities (2013: 165). I aimed for the unnamed, laughing woman in my story to also have 
this dual quality: her eyes glow 'in a half-crazed sort of way' as she becomes excited about her upcoming art exhibit which will showcase knitted animals. The woman artist's medium is knitting to represent the act of writing because just as Cixous' claimed that 'woman must put herself in the text' (1976: 875), I imagined this character as myself - the writer, the embodiment of both Medusa and Arachne, the Goddess of classical mythology who embroidered defiantly honest stories for which she was punished (Habens 2016). This is hinted at when 'the same face peered out of each lens' as Clio is looking into the writer/Medusa/Arachne woman's glasses. The women in the kitchen, the writer/Medusa/Arachne figure clearly positions the text in the realm of Écriture féminine through her direct gaze at the protagonist Clio because as Susan Bowers observes, 'the antidote to the male gaze, and one avenue to women reclaiming their own sexuality, is the female gaze: learning to see clearly for themselves...' (Bowers 1990: 218). When Clio imagines the woman's art as 'woolen bunnies or lambs ... across a white gallery floor,' the floor becomes symbolic of the white paper onto which the text is woven, and the knitted animals are my constructed characters. 'Erato' draws largely from memories of my lived experience and so Clio is a fictional representation of my younger self, although it remains to be seen whether this embroidered text will incur the wrath of Goddesses or Gods. return to text

[3] TS Eliot's modernist poem The Wasteland alludes to hundreds of other texts to construct meaning in the face of 'the decay of culture in modern Western society when many consider present experience as chaotic, fragmentary, sterile and meaningless' (Crews 1998: 19). That Clio can read this poem without becoming sick is intended to demonstrate her character's disillusionment with her present reality as well as flag to readers the heavy reliance on intertextuality throughout 'Erato'. The Wasteland, which contains 'a multiplicity of discourses or heteroglossia' (Crews 1998: 19), is designed to highlight the multitude of intertextual allusions perpetrated both overtly and covertly throughout my story. return to text

[4] Happening upon this surrealist poem while writing my story was exhilarating because contained within it is a line I could appropriate to demonstrate what Charlotte Currie observes is the canonical relationship between the Medusa and transformation (Currie 2011: 170). The image of Clio's head as writhing with glow worms comes from Gascoyne's line, 'and when she sings her hair stands on end and lights itself with a million little lamps like glow worms' (Gascoyne 1933). Here I've transformed the black snakes into glow worms to neutralise the misogynistic connotation of evil associated with female power, just as Cixous transforms the longstanding popular image of Medusa as wicked, alluring, and dangerously seductive into a beautiful, laughing woman, albeit still with writhing black snakes (1976). So while 'Erato' is a text 'constructed of a mosaic of quotations' which I absorbed and transformed (Kristeva 1986: 37), or in Roland Barthes' terms 'a new tissue of past citations' (Barthes 1981: 39), the process of embroidering these disparate pieces of other texts was deliberate and often I had the feeling of being a literary 'bowerbird', picking out fragments, ideas and images from other texts and deliberately weaving them into my story, essentially making them function as new symbols and tools of Écriture feminine. In his discussion ofEliot's 'Tradition and the individual talent' (1965), Paul Williamsobserves that 'it is imperative that writers be conscious of their intertextuality' to engage in a dialogue with the past and with tradition. Furthermore, Williams notes that 'bowerbirding' is a common narrative practice supporting the praxis of intertextuality and 'sanctioned as bone fide research in academia' (Williams 2015: 175). return to text

[5] The reference to Fay Weldon's novel Down Among the Women (1971), a scathingly ironic work whose female narrator reveals women's experiences of motherhood, contraception, divorce, abortion, suicide and friendship in the post-World War II period, is intended to overtly communicate to readers that 'Erato' lies in the region of Écriture feminine. Massie observes that Weldon's 1970s novels 'represent the sharpest statement of the feminist position' (Massie 1990: 38). But this feminist position is a complex, astute one, full of overlapping greys rather than a simple black/white view of female/male politics. For example, though readers are treated to such passages as: 'Down here among the women you don't get to hear about man maltreated; what you hear about is man seducer, man betrayer, man deserter, man the monster' (Weldon 2014: 66), women are not painted as purely innocent victims, but shown to be eager to please men, and spiteful and rivalrous toward each other. Dowling notes that the female characters in the novel'still see men as central to their existence and the likely repositories of any happiness they might have the potential to 
obtain' (Dowling 1998: 47). In addition, Weldon's black sense of humour can be gleaned when considering that one character, Helen, whose romantic relationship fails, is introduced to readers at the outset as having made the decision to kill herself because 'anything was better than ending up like the rest of us, down here among the women' (Weldon 2014: 2). That Clio goes to read this novel, but instead kisses Tomas, not wanting to 'remember who she was', is intended to highlight her struggle with establishing a sense of identity apart from her romantic relationship with Tomas. Furthermore, this intertextual reference to Weldon's novel serves to foreshadow the complex turn of events, coloured by greys rather than black and white, that ensue between Clio and Tomas. return to text

[6] The laughing woman Clio encounters in her dream refers to Cixous' claim that 'you only have to look at the Medusa straight on to see her. And she's not deadly. She's beautiful and she's laughing' (Cixous 1976: 885). But Clio suspects the woman is mocking her, which suggests that her attitude towards her own creative drive is ambiguous or confused, marred and tainted in some way so that she can't be sure whether the Medusa is a positive or negative force in her life. return to text

[7] Some of the intertextual references in this scene allude to Elaine Showalter's notion of a 'gynocritical' approach to women's writing which is 'concerned with woman as writer with woman as the producer of textual meaning, with the history, themes, genres and structures of literature by women' (Showalter 1979). The books written by female authors strewn around Clio's room are testament to Showalter's 'gynocritical' approach to women's writing: Woolf, Plath, Byatt. By gathering these works together in Clio's room, I hope to invite readers to look for connections between them, as Showalter observes that 'it is because we have studied women writers in isolation that we have never grasped the connections between them' (1979). One connection is that the women writers I've included in 'Erato' have embraced writing about women's lives, and particularly about the obstacles in the way of women writers. That Clio's law books 'remained on her desk like dusty monoliths, left open and untouched for months at a time', while novels written by women litter her room, it should be clear to readers that Clio's passions lie in literature, language and writing rather than the law. This suggestion is made obvious when Sister Teresa finds Gertrude Stein's Tender Buttons (1914) open on top of a law book, as though Clio had been reading it before she was struck into a 'catatonic state'. According to Adam Fieled (2011), Stein's work is so experimental as to almost defy criticism, causing it to be positioned alongside other 'non-sense' avant garde explorations such as cubism and dadaism. But my understanding of Tender Buttons, in terms of how I want it to function as an intertextual reference in 'Erato', is more in line with Michael Edward Kaufmann's perspective, which claims that through moving words around on the page, Stein 'forces us to reexamine the way we read by creating a "visible writing" ... Stein revises meaning so that we see it again, and see it as if for the first time' (Kaufmann 1989: 460). In the guise of a madwoman, Stein highlights and questions the conventions of writing, of type and textual syntax to overthrow the delusion of reality presented by seemingly natural language systems: 'In Tender Buttons Stein seeks to find the source of the "program", this writing that writes herself, writes her world' (Kaufmann 1989: 455). But the full significance of the presence of Tender Buttons in Clio's room registers to me only now after rereading 'Erato' as a critic, in the light of critiques of Stein's poem. It's as though I'm seeing my text for the first time, as a new tapestry filled with infinitesimal layers of interconnections woven into a web of intertextual links. Just as Tender Buttons cannot be read "without being aware how "chosen" each word is' (Kaufmann 1989: 449), 'Erato' cannot be read without an awareness that each text referred to by title has been consciously chosen to draw readers' attention to its significance in the context of all the other texts which appear in the textual tapestry. Considered individually, the texts which make up the greater tapestry might be viewed as referential dot points in a larger 'dot-to-dot' picture: readers must conceptually join the dots to glean the whole meaning of the story. While writing 'Erato', although I felt an indefinable unconscious force powering the creative flow, and like a painter or sculpture, I intuitively dabbed and kneaded words across the white page as the narrative took shape, simultaneously I deliberately selected and read other texts before scattering their titles over the pages, revealing the space or connections between them. But this new space, this intertext which is visible only after readers 'join the dots' is not, as Barthes claims, 'a general field of anonymous formulae whose origin can scarcely ever be located; of unconscious or automatic quotations, given without quotation marks' (Barthes 1973), but a carefully constructed, multi-dimensional universe alive with voices echoing from different points in time. Furthermore, the boundaries of this universe do not have to be limited to the page, but can be 
widened to include other mediums and works of art such as painting and even film making. Clio's room is evidence of the power of intertextuality to widen the boundaries of literary universes: 'Dead Poets' Society was playing on the television' and 'tacked on the wall above her was a large Dali print with blue and brown hues. Melted clocks peered out from within.' return to text

[8] This artwork is a reference to 'Pigeons', a performance art piece enacted in the 1990s by Brisbane artist Jeremy Hynes whose work was largely influenced by surrealism ('Jeremy Hynes: Performances' 2007). I chose to refer to this piece in 'Erato' with the intention of further neutralizing and transforming the Medusa as a symbol of women's wicked and inherent proclivities. In Tomas' artwork, pigeons are gathered around his head; in Clio's dream, she sees a woman with snakes for hair; in Clio's imagination, her hair is alive with glow worms. These images, when viewed in the light of each other, are intended as incarnations of the Medusa, with Tomas' pigeons and Clio's glow worms symbolic of my desire to undo the demonization of female as opposed to male power. Furthermore, by associating the Medusa symbol with Tomas, a male character, my intention was to address Cixous' idea that 'phallocratic ideology has claimed more than one victim ... man has been handed that grotesque and scarcely enviable destiny of being reduced to a single idol with clay balls' (Cixous 1976: 884). return to text

[9] This ending leaves readers with no illusions regarding the fact that 'Erato' uses intertextuality to explore questions to do with Écriture féminine. Although, what 'happens in the end' regarding whether the moon is a woman's ruler, and whether this is indeed an immutable fact of nature, is a question which calls for readers to consider the overall meaning of 'Erato', rather than how Weldon's novel plays out. But many readers might be baffled by this question, offended even or annoyed, as to answer it would require some understanding of the connections between the intertextual 'dot-points' given throughout the story: it requires readers to read beyond the boundaries of the white page onto which the textual tapestry of 'Erato' is woven. Or perhaps not. Perhaps the story can be read simply as a narrative about a woman's life, and that would be enough for some. Other readers who are more familiar with the use of allusion and intertextuality to communicate meaning, might want to investigate further. Which begs the question of whether 'Erato', much like Paul Williams' 'The Absence of Theory' (2012), could be considered academic discourse presented as a short story rather than a conventional essay, using intertextuality to discuss Écriture féminine. However readers choose to approach 'Erato', and from whatever angle the allusions and intertextual references in the infinitesimal universe of the text are interpreted, through weaving the tapestry onto this white page, I have gained a greater, richer understanding of myself as the writer/Medusa/Arachne/Clio/Erato figure. return to text

\section{Works cited}

Alban G 2013 'Medusa as Female Eye or Icon in Atwood, Murdoch, Carter, and Plath', Mosaic: A Journal for the Interdisciplinary Study of Literature 46, 4: 163-182: https://musejhu-edu.ezproxy.usc.edu.au/article/531068/pdf(accessed 7 May 2017) return to text

Barthes R 1981 'Theory of the Text', Untying the Text, ed R Young, Routledge, London: 3147 return to text

Bowers, SR 1990 'Medusa and the Female Gaze', NWSA Journal 2, 2: 217-235: http://www.jstor.org.ezproxy.usc.edu.au:2048/stable/4316018 (accessed 7 May 2017) return to text

Cixous H, 1976 'The Laugh of the Medusa', trans K Cohen \& P Cohen, Signs 1, 4 (Summer): 875-893: http://www.jstor.org/stable/3173239?seq=1\#page_scan_tab_contents (accessed 4 May 2017) return to text

Crews B 1998 'Tradition, Heteroglossia and T.S. Eliot's "The Waste Land”, Atlantis 20, 2: 17-25: http://www.jstor.org.ezproxy.usc.edu.au:2048/stable/41055510 (accessed 7 May 2017) return to text

Currie C 2011 'Transforming Medusa/Transformando A Medusa', Amaltea. Revista De Mitocrítica 3: 169-181: https://search-proquest- 
com.ezproxy.usc.edu.au/docview/922063776?accountid=28745 (accessed 7 May 2017) return to text

Dowling F 1998 Fay Weldon's Fiction, Fairleigh Dickinson UP, Madison NJ return to text

Fieled, A 2011 'Contextualists and Dissidents: Talking Gertrude Stein's Tender Buttons', Cordite Poetry Review (1 December): https://cordite.org.au/essays/contextualists-anddissidents-talking-gertrude-steins-tender-buttons/ (accessed 5 May 2017) return to text

Gascoyne, T 1933 'And the Seventh Dream is the Dream of Isis', David Gascoyne: http://www.connectotel.com/gascoyne/gascp10.html (accessed 7 May 2017) return to text

Habens, A 2016 'Women, Writing and the (original) Web', Textile 14, 3: 348-359: http://dx.doi.org.ezproxy.usc.edu.au:2048/10.1080/14759756.2015.1108592 (accessed 7 May 2017) return to text

'Jeremy Hynes: Performances' 2007 IMA Brisbane: http://www.ima.org.au/jeremy-hynesperformances/ (accessed 7 May 2017) return to text

Kaufmann, ME 1989 ‘Gertrude Stein's Re-Vision of Language and Print in “Tender Buttons", Journal of Modern Literature 15, 4 (Spring): 447-460:

http://www.jstor.org/stable/3831601 (accessed 7 May 2017) return to text

Kristeva, J 1986 'Word, Dialogue, and Novel', The Kristeva Reader, ed T Moi, Columbia University Press, New York: 34-37 return to text

Massie, A 1990 The Novel Today: A Critical Guide to The British Novel, 1970-1989, Longman, London return to text

Maupassant, G de 1987 [1884] 'The Jewelry', in CE Bain, J Beaty \& JP Hunter (eds) The Norton Introduction to Literature (4th edn), WW Norton \& Company, New York return to text

Showalter, E 1979 'Toward a Feminist Poetics', in M Jacobus (ed) Women Writing and Writing about Women, Routledge, London:

http://historiacultural.mpbnet.com.br/feminismo/Toward_a_Feminist_Poetics.htm\#_ednref22 (accessed 7 May 2017) return to text

Stein, G 1914 Tender Buttons, Dover Publications, New York 1997 return to text

Weldon, F 2014 [1971] Down Among the Women, Head of Zeus, London return to text

Williams, P 2012 'The Absence of Theory', New Writing 9, 2 (July 1): 216-227:

http://www.tandfonline.com/doi/abs/10.1080/14790726.2011.639896 (accessed 7 May 2017) return to text

Williams P 2015 'Plagiarism, Palimpsest and Intertextuality', New Writing: The International Journal for the Practice and Theory of Creative Writing, Routledge, London: http://www.tandfonline.com/doi/abs/10.1080/14790726.2015.1036887 (accessed 29 May 2015) return to text

Megan Anning is obsessed by Bohemianism and the romantic idea of the 'starving artist'. Her story 'Dandelions' recently appeared in the West End Magazine and is an extract from her first novel which she is working on as part of the Masters of Professional Practice (Creative Writing) course at the University of the Sunshine Coast. She has a Bachelor of Social Science (Sociology) from the Queensland University of Technology. 


\section{TEXT}

Vol 21 No 2 October 2017

http://www.textjournal.com.au

General Editor: Nigel Krauth. Editors: Kevin Brophy, Enza Gandolfo \& Julienne van Loon

Creative works editor: Anthony Lawrence

text@textjournal.com.au 
TEXT poetry

\section{Yuan Changming}

\section{5 poems}

\section{Towards Taoism}

With a storm

With a gull

With your breath

Goes the thought

With a vague vision

Beyond the bogland

With your heart

Hawking aloud in the wild

With dripping blood

An unformed concept

A shoal of consciousness

Bubbling with feeling

With a photon

With a quantum

With your mind concentrated

On a twisted other

\section{Copse}

Standing straight against the frozen sky

Your skeletons are the exquisite calligraphy

Of the season

Your name is writ

Not in water

But with wind

\section{Swirling}

Among the mixtures of

Seven primary colors, the painting

Gives rise to a swirl

Turning fast enough

To send you up to a little cloud

Like the Zhuangzian Peng gliding through

The serenity of autumn sky 
Neither the bird nor you cast

Any shadow down as the earth

Keeps rotating as leisurely

As any other day beyond the black hole

When you return and stand on a

Hilltop, the painting is still

Unfolding itself, but the bird has

Vanished high up into another universe

\section{Directional Denotations}

South: not unlike a raindrop

on a small lotus leaf

unable to find the spot

to settle itself down

in an early autumn shower

my little canoe drifts around

near the horizon

beyond the bare bay

West: like a giddy goat

wandering among the ruins

of a long lost civilization

you keep searching

in the central park

a way out of the tall weeds

as nature wraps new york

with mummy blue

East: within her beehive-like room

so small that a yawning stretch would readily awaken

the whole apartment building

she draws a picture on the wall

of a tremendous tree

that keeps growing

until it shoots up

from the cemented roof

North: after the storm

all dust hung up

in the crowded air

with his human face

frozen into a dot of dust

and a rising speckle of dust

melted into his face

to avoid this cold climate

of his antarctic dream

he relocated his naked soul

at the dawn of summer 


\section{Karma Casting: a Wuxing Poem}

- Believe it or not, the ancient Chinese 5-Element Theory accounts for us all.

1 Metal (born in a year ending in 0 or 1 )

- helps water but hinders wood; helped by earth but hindered by fire

he used to be totally dull-colored

because he came from the earth's inside

now he has become a super-conductor

for cold words, hot pictures and light itself

all being transmitted through his throat

2 Water (born in a year ending in 2 or 3 )

- helps wood but hinders fire; helped by metal but hindered by earth

with her transparent tenderness

coded with colorless violence

she is always ready to support

or sink the powerful boat

sailing south

3 Wood (born in a year ending 4 or 5)

- helps fire but hinders earth; helped by water but hindered by metal rings in rings have been opened or broken

like echoes that roll from home to home

each containing fragments of green

trying to tell their tales

from the forest's depths

4 Fire (born in a year ending 6 or 7 )

- helps earth but hinders metal; helped by wood but hindered by water

your soft power bursting from your ribcage

as enthusiastic as a phoenix is supposed to be

when you fly your lipless kisses

you reach out your hearts

until they are all broken

5 Earth (born in a year ending in 8 or 9)

- helps metal but hinders water; helped by fire but hindered by wood

i think not; therefore, I am not

what I am, but I have a color

the skin my heart wears inside out

tattooed intricately

with footprints of history

Yuan Changming, nine-time Pushcart and one-time Best of Net nominee, published monographs on translation before moving out of China. With a Canadian PhD in English, Yuan currently edits Poetry Pacific with Allen Yuan in Vancouver. Credits include Best Canadian Poetry, Cincinnati Review, BestNewPoemsOnline, LiNQ, Threepenny Review and 1289 others across 39 countries. 


\section{TEXT}

Vol 21 No 2 October 2017

http://www.textjournal.com.au

General Editor: Nigel Krauth. Editors: Kevin Brophy, Enza Gandolfo \&

Julienne van Loon

Creative works editor: Anthony Lawrence

text@textjournal.com.au 


\section{TEXT prose}

\section{Amy T Matthews}

\section{Thinking About Camels}

I assume there was an actual camel once. The one that became proverbial because its deathwas just so damn poetic. I assume it was an Arabic camel (the proverb being Arabic), standing in the blinding heat, being all sullen the way camels are, their black eyes spiteful as they chew whatever they chew. I have no idea what camels eat. They spit, I know that. When they get mad, they spit. This camel probably spat, as its idiot master kept loading it up.

There it was, in the shimmering, headachy heat, probably besieged by stinging flies, glaring sullenly as load after load was piled onto his back. It might have made a noise; thatdiscordant unpleasant noise camels make, and yes it probably spat. But it was just a camel.It didn't have a say in what was loaded on its back. Its knees probably locked, to withstandthe weight, then trembled. It might have sunk a little into the sand. And the idiot kept loading it up and, at the very last, threw a straw on top. The straw was clearly added by thestorytellers. What possible use is a straw and why would you pack one?

In some versions of the story it's a feather. One version has a monkey instead of a camel, and a melon instead of a straw. It's kind of beside the point. The straw is poetic. If there was an actual, historical camel (and I bet there was at some point), there was probablya bundle that got thrown on at the last, and not an actual straw. The idiot master was probably a merchant; the bundles and packages were probably goods; he probably stood to make a lot of money off that camel's back. Anyway, he threw the last straw (bundle) on and, snap, there went the camel's back.

It didn't die. It wouldn't have. A broken spine isn't lethal. It would have gone down,clumsily, without grace. The camel would have been in agony, distressed, screaming. And the merchant would have killed it, to put it out of its misery. And then he would have bitched and moaned about having to buy another damned camel. 


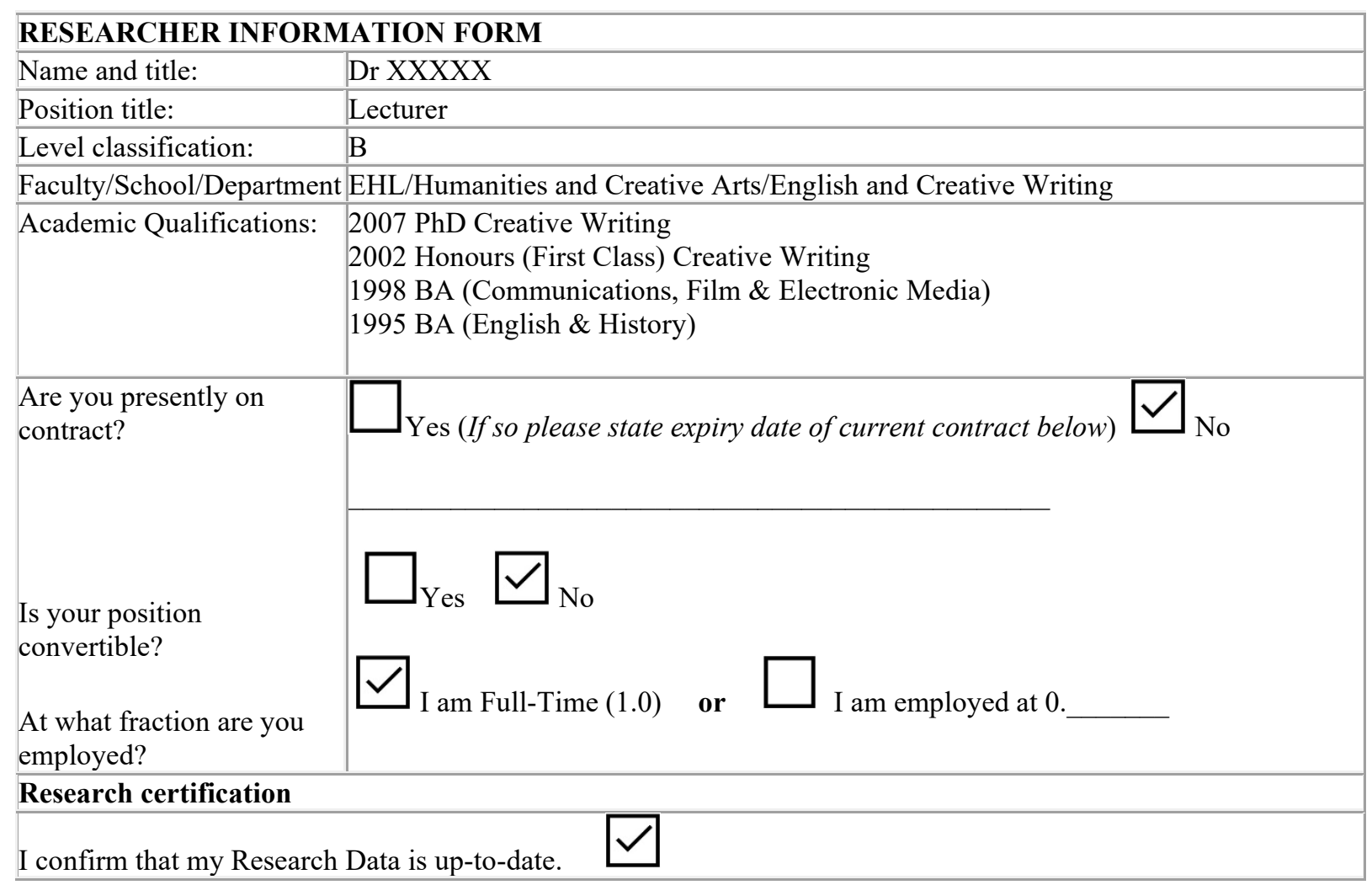

\section{To: XXXXX}

From: RLP Literary Agents

Subject: Contract and

Timelines

\section{Hello XXXXX,}

Firstly, congratulations on the shortlisting. Excellent news. When is the winner announced? Please keep me in the loop and I'll make sure the news is posted on our social media and website.

I'm expecting a draft contract to arrive in the next few weeks for The Happy Ending. I will forward it on with mynotes attached and we can discuss then. I have a few suggestions at this stage - are you free for a chat? Would like to know your thoughts on international rights and whether we want to enter into a multi-book contract, offer rights of first refusal, or keep our options open. Caroline isenthusiastic about the book and wants me to pass on how excited they are. How soon can you write a sequel?

The literary book is with four publishers at present, with responses due back to me by mid-month. I know this oneis dear to your heart. Fingers crossed for it.

You mentioned you need a publication ASAP for work. The romance will be out late next year (if we 
counted as partof your publications? Or does it absolutely have to be a 'literary' book? You said you're feeling 'up against the wall'. I hope the short story you had out last year counts? The novel was released when... 2011? And your academicbook a year or two later? Considering that the market is settling finally, after the flux of the past few years, we should be able to place your books soon. If the romance can be published in the next 12-18 months, we can then tryand find a home for the other two romances.

Can you forward me a synopsis for the next literary novel? From memory you just wrote an outline for a grant or fellowship application? I think that project sounds marketable - more marketable perhaps than the last coupleof literary books. What kind of timeline are you working on?

Reviewing our last discussion, you are currently workingon a sequel to The Happy Ending and this next literary project? Are there any other irons in the fire that I shouldknow about? How fast can you work?

Best

$\mathrm{R}$

How fast can I work?

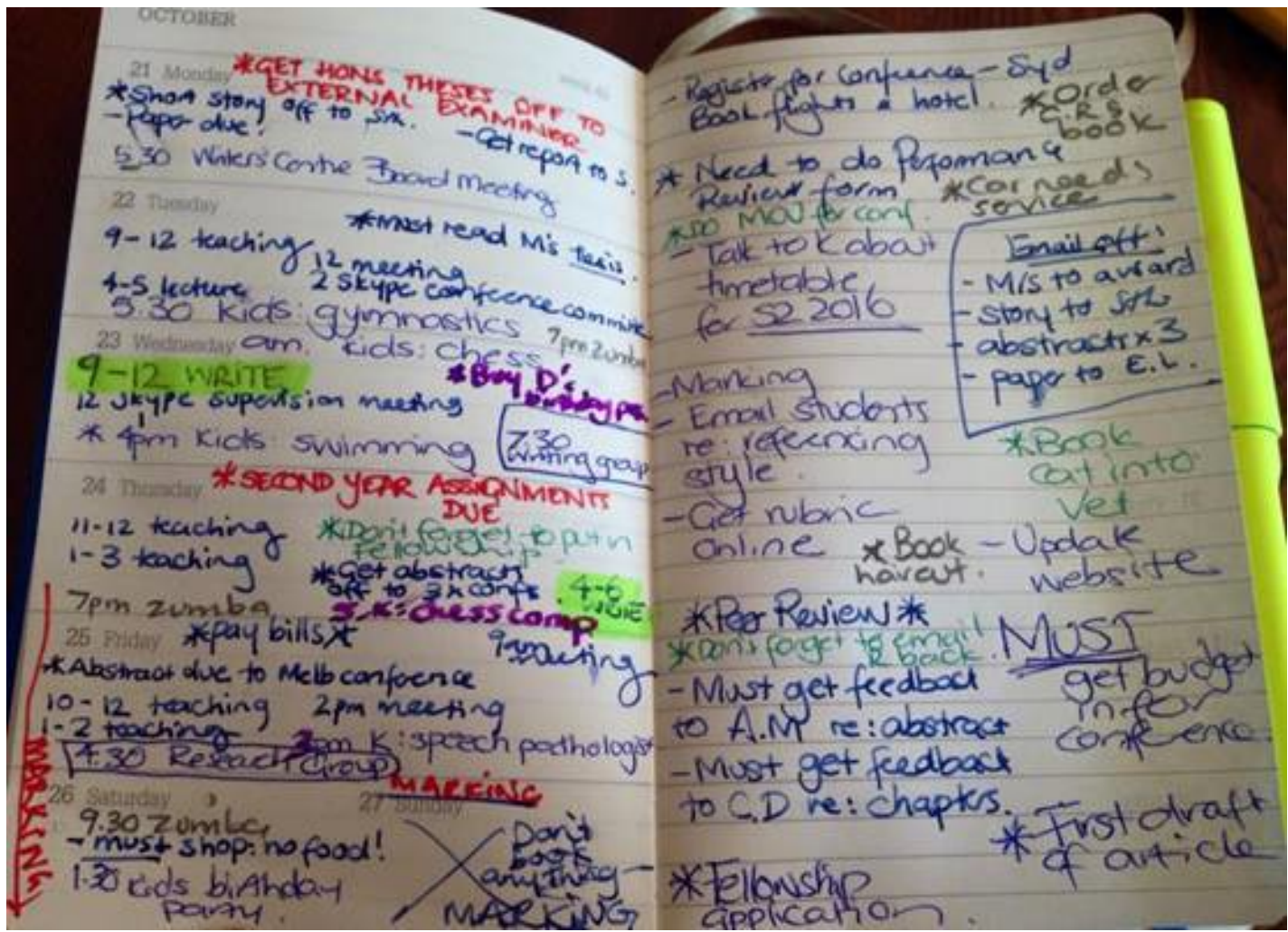


To: XXXXX

Subject: Performance Review

\section{Dear XXXXX,}

Your performance review has been scheduled for next

Monday. Please fill out the attached forms and return themby Friday, so your supervisor has time to read them beforeyour meeting.

Regards

HR

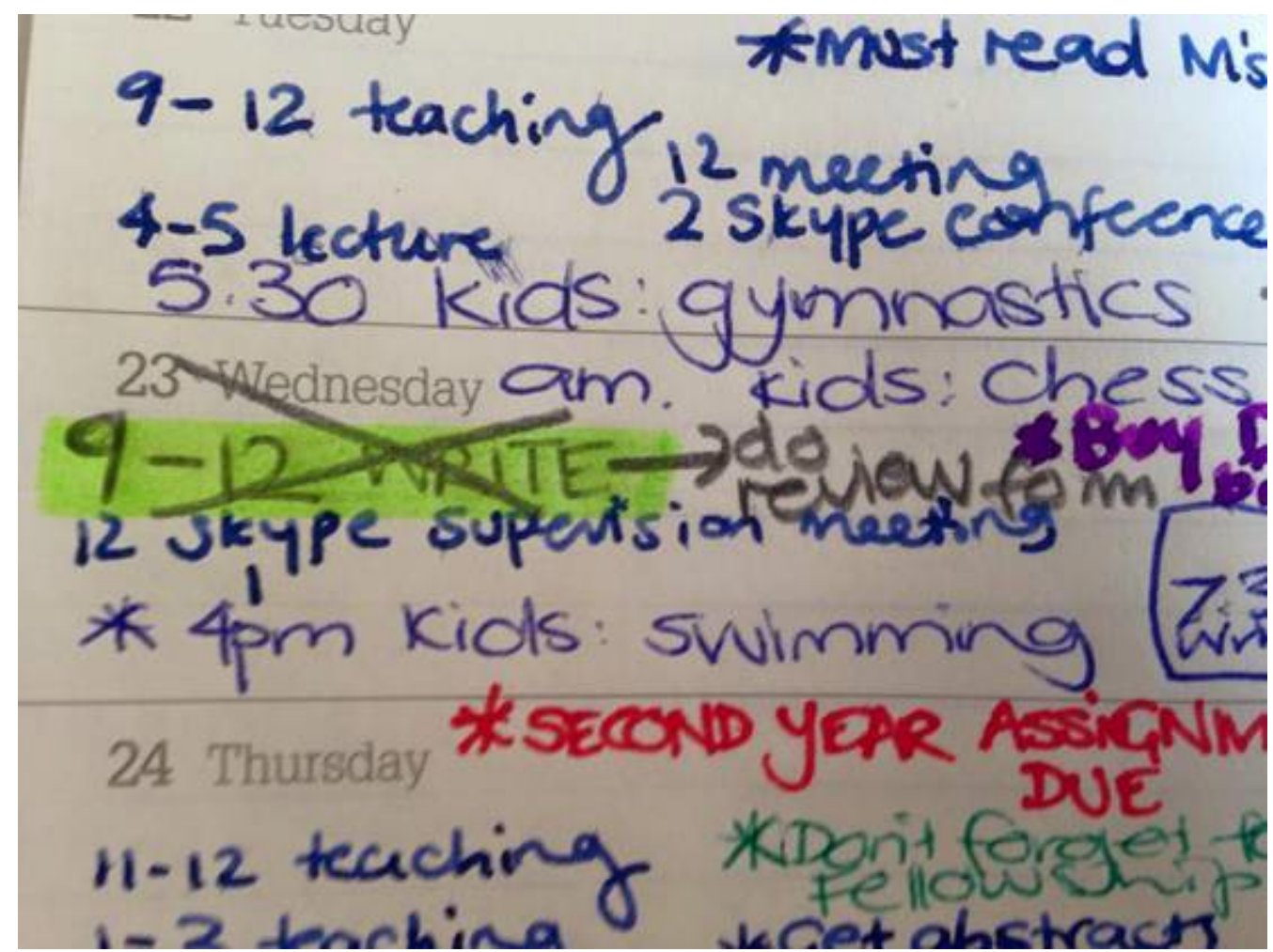

They say there aren't any camels left in the wild. They were domesticated thousands and thousands of years ago, because they can travel long distances without much nourishment, through terrains where no road can be laid. Self-sufficient animals, they have large soft feetthat spread to let them walk on shifting sands. Useful, camels were put to use. They're the workhorses of the desert; preferred, because you don't have to feed them much. They're patient and they endure. So you don't have to worry about them startling and bucking and galloping off. They're plodders. But at least they're more exotic than cows.

I try to imagine telling the truth on my performance review. Is it research to spendan hour thinking about camels? 


\section{ACADEMIC STAFF \\ PERFORMANCE \\ REVIEWFORM A \\ SECTION 1}

\section{RESEARCH AND/OR CREATIVE ACTIVITY}

13.1 Activities since last review (refer to Note \#13.1 in Guide to Form A)

- I submitted final drafts of two novels (one literary, one romance) to my

- agentI had a short story published

- I submitted four abstracts for conferences

- I did two public readings of work in

- progressI submitted a novel to an award

- I applied for a fellowship

- I was awarded two internal

- grantsI've been thinking about camels

- I bought a lot of new books and lined them up on my bookshelf; I haven't got time toactually read them

- I went to conferences and wondered how all these people manage it; I wonder ifthey'll tell me the secret

: I got a serious haircut in the hope that it would make people take me

- seriously I've been crying a lot and thinking about divorce and death and depression andgrowing old and what romantic love really means in the face of real life I've been juggling single-parenthood and working full time and I never get time towrite anymore and I wonder what the point of it all is

13.2 Proposed activities for current year (refer to Note \#13.2 in Guide to

- Form A)First draft of new literary book

- Working on a draft of new romance

- Short story about being a writer in the academy

- Three papers to be presented at conferences

- Organising national conference for 2016

- Paper co-authored with PhD student to be

- submittedWrite anything at all

13.3 Future plans (refer to Note \#13.3 in Guide to Form A)

Cocaine? Then I wouldn't need to sleep and could write at night? I can't afford cocaine.

Crystal meth?

Quit my job? We'd be homeless and hungry, but at least I would have time.

These days time is the new gold. Invaluable. Perhaps glittering on the ground in somedistant land, where I could go and buy a plot and gather it up.

Become someone else - one of those people who seem to be able to turn off theirperson-hood and be a worker bee.

Get interested in bees. They're more highly thought of than camels. 
In the northern hemisphere the death of the honeybee has reached biblical proportions. In far north Oregon in the United States a woman named Joy clocked

off one night and emerged into the Wal-Mart car park to find the corpses of 50,000 bees. I don't know how she counted them all. Did they hire someone to count the bees? Whoever it was has a burgeoning career, as bees are dropping from the sky at unprecedented rates. The age of thebee is drawing to a close.

Colony Collapse Disorder is when all the worker bees disappear simultaneously. Bees have disappeared before from time to time; their sudden absences turn up in the history books under the names disappearing disease, spring dwindle, May disease, autumn collapse, and fall dwindle disease. But this time it's different. Never before have bees disappeared, dwindled, collapsed in their millions, across an entire hemisphere. Never before have they been asked to make honey from fungicides. And as they die, the fields fallfallow. This is what happens when the workers fall from the sky.

There are 1500 species of native bees in Australia and not one has fallen dead to the ground in a Wal-Mart car park. Not least because we don't have Wal-Mart. But even the Target car parks are dead-bee free. We use insecticides and fungicides. But we never did getmuch honey from native bees. In fact they're not really much like bees at all - they're morelike a kind of wasp. That's our disappearing disease; our wasps disappeared into the genus of bee, victims of the usual European history of trying to fit new things into existing boxes. Like the camel - most of the time the creature we think of as a camel is actually a dromedary.

No one writes poetry about dromedaries. Even though they run feral through the mid-north, galloping free: wild. Wild camels haven't existed for thousands of years; and yetthere they are, striding through the red dust of the great Australian emptiness. Imported to serve, they broke free. What's more poetic than that?

I will write about camels.

Nothing else seems to work.

Dr Amy T Matthews is a Lecturer in Creative Writing at Flinders University and a member of the JM Coetzee Centre for Creative Practice. She has published short stories in collections including Best Australian Stories, and been long-listed for the Australian/Vogel literary award. Her novel End of the Night Girl won the 2010 Adelaide Festival Unpublished Manuscript Award, was published by Wakefield Press in 2011, and was subsequently shortlisted for the 2012 Dobbie Literary Award and the 2012 Colin Roderick Award. Her book length exegesis Navigating the Kingdom of Night is published by Adelaide University Press. Amy also writes historical romantic-adventure novels under the name Tess LeSue, is a past winner of the Anna Campbell Award and has been shortlisted forthe Romance Writers of Australia's EmeraldPRO, Emerald and STALI Awards. Tess's novelBound for Eden is in stores now.

\section{TEXT}

Vol 21 No 2 October 2017

General Editor: Nigel Krauth. Creative works editor: Anthony Lawrence 
TEXT prose

Peter Nash

Murder in the Office of Final Editing

...They never did find the killer and for all I know

Elle DuBois is still drinking in the El Paradiso.

The End.

The story was good, real good; so good I was almost ready to cash the check. All I had to do now was an edit and ensure it arrived on Joe 'Rice' Reynold's desk at seven sharp. I had just signed my life away for a brand-new Harley Davidson and Rice was the kind of guy that didn't like to wait.

\section{Trouble Talks}

Twice

Three weeks before that I' $d$ been on my fifth in the El Paradiso club, Cuba. I told myself, just one more and then walk away. Forget the whole sorry mess; catch the next plane out. Forever. The glass arrived. A fancy number, sporting two straws with sliced pineapple skewered and split twice straddling the rim.

'Hey,' I looked at the bartender busy drying his lily-white hands into a bright red apron, 'I ordered a scotch on the rocks not a...'

Before I could finish, a double-honeyed voice laced with nicotine said, 'You look like the kinda guy that could help a girl like me out.'

I caught a perfume scent through the cigar smoke and dreamt I heard the sweet sound of silk stockings stretching slowly against a pair of spiked heels.

'What's a dame like you...'

'Don't,' she said. 'What's your name?'

I took my time assembling the words, but she beat me to the punch.

'I like a man that takes his time.'

'I like a dame that knows what she wants,' I

replied. 'Where the hell have you been?'

'More to the point,' she said flicking her 
ash straight at me, 'Where the hell have you been?'

I poured a stiff drink and took a good slow hit then read this part of the story again. I knew it flowed ok, but something wasn't right. I poured another double rye, took my time and read it again. Then it smacked me. Hard. Of course. Of course, it didn't add up. If Elle DuBois had been on the level there was no possible way she could have been in the El Paradiso club when she said she was. I double checked her story with my notes. There it was. She told me she had been drinking pina coladas in the El Paradiso with her friend Joan, and Joan's new guy Eddie, at 4:20 and at exactly 4:35 the three of them had caught a cab across town to the Green Flamingo.

I compared her version with Joan's story. According to my journal Joan had said that before their rendezvous with Elle in the El Paradiso, they were at Havana Joe's café waiting for Captain and Mrs Waterhouse to take them out cruising on the bay. I distinctly remembered asking them what time that was. And I remembered how they both replied that the time had been $4: 15$, and that they were sure of it because it was always at that time Pepe the owner of Havana Joe's went upstairs for a nap and usually didn't reappear until quite late in the evening. This was important because if Charles and Irene Waterhouse were still at home while Eddie and Joan were drinking coffee at Havana Joe's, then that meant the killer was definitely at the Waterhouse's residence before they vanished. I went back to the beginning of the story.

'The End.' Those words didn't seem so final now, and that lousy check looked like it might bounce.

I was out of rye so I selected a bottle of Bombay Sapphire from the archtop cabinet with the burled walnut cabriolet legs, poured a good amount and went through it all again. I had the suspects in the right location and timed correctly, I was convinced of it. The way I figured it was, if it usually took Charles and Irene Waterhouse twenty minutes to arrive at Havana Joe's from their residence further around the Bay it would have been impossible for Elle DuBois to have been in the club lounge of the El Paradiso at 4:25 like she claimed. I poured another shot, slammed it fast and checked the clock.

Painstakingly, I wrote down everything I could find in my notes, even reading through the initial entries I had long since discounted. According to my records Elle DuBois was in the El Paradiso at 4:20, and then left with Joan and Eddie in a taxi on their way to the Green Flamingo at 4:35, while I was on my way to talk with Elle at the El Paradiso. If this was true, then how the hell could I have missed the detail about Eddie and Joan drinking coffee at Havana Joe's at the time they claimed. Another tall one over extra ice and I went back to it.

The hell with Eddie, Joan and Elle. Work backwards from the Waterhouses and try to figure it out that way. They had never arrived at Havana Joe's to meet Eddie and Joan like arranged, and it wasn't until two days later that both of their bodies had washed up twenty miles away on the eastern shore. I was certain I had everyone in their place and squared away. Elle DuBois at 4:20pm waiting for me in the El Paradiso. Joan and Eddie at Havana Joe's waiting for the Waterhouses. Captain and Mrs Waterhouse missing from around the time they were supposed to keep their appointment with Eddie and Joan. 
Then I realised that if Elle had been lying all along and hadn't gone with Joan and Eddie to the Green Flamingo and if Pepe didn't take a nap upstairs every day like Joan and Eddie said he did, then why were the Waterhouses missing their index fingers and the third toe on each left foot when they were found by Santo the fisherman?

Maybe it was the gin. So I went over to the fridge, pulled out an ice cold long-neck and chugged it in one swallow. Sat on my old crate covered with the Mexican blanket and killed Elle Dubois, Joan, Eddie, Irene, Charles, Pepe and Santo, then tore up the story and started again.

The End.

Peter Nash is an Honours student studying creative writing at Griffith University.

\section{TEXT}

Vol 21 No 2 October 2017

http://www.textjournal.com.au

General Editor: Nigel Krauth. Editors: Kevin Brophy, Enza Gandolfo \&

Julienne van Loon

Creative works editor: Anthony Lawrence

text@textjournal.com.au 
TEXT poetry

\section{Chelsea Avard}

\section{Blue Eyes}

I can't write blue-eyed poems

Like his

Maybe never could

I remember that desire

As though it belonged to someone else

I can write my little things

My strange little things

That think and feel

I care more about them than before

And I judge them less

I can't make things

That are light

Full of hope and air

I think them and I feel them

But they turn to nothing on the page

I can make these things that hold

Things that grind

That push back

Press

Like thumbs into soft flesh

Green-eyed things

Redheaded things

Sharp-chinned things

Like bodies

Thinking less and doing more

Like a hand beneath your chin

Like teeth grazing your lips

A fingernail tracing your spine

Blue gaze caught in mine 
Chelsea Avard is a writer and teacher from Adelaide. She is co-editor of the short fiction and poetry anthology The Body. She holds a PhD from The University of Adelaide, where she currently works as coordinator of the Writing Centre. Her short fiction and poetry has been included in a range of works including the Sleepers Almanac, anthologies by Wakefield Press, University of Philippines Press and Midnight Sun, and online publications Verity La and Red Fez. Her poem, 'How We Stay', won the 2017Verandah Literary Award.

\section{TEXT}

Vol 21 No 2 October 2017

http://www.textjournal.com.au

General Editor: Nigel Krauth. Editors: Kevin Brophy, Enza Gandolfo \&

Julienne van Loon

Creative works editor: Anthony Lawrence

text@textjournal.com.au 